https://doi.org/10.18778/1509-877X.2020.02.03

\title{
REVIEW OF THE RULES ON THE SPECIAL SCHEME FOR SMALL ENTERPRISES UNDER THE VAT Directive 2006/112/EC
}

Summary. On 18 January 2018 the Commission adopted a proposal for a Council Directive amending Directive 2006/112/EC on the common system of value added tax as regards the special scheme for small enterprises. The proposal belongs to the reform package announced in the VAT Action Plan aimed at modernising the EU VAT system in order to make it simpler, more fraud-proof and business-friendly.

The proposal aims at updating the VAT rules on the special scheme for SMEs and bringing them closer to the reality of the single market as well as adjusting them to the destination-based taxation. The SME package proposal was subject to a two-year discussion in the Council. Eventually, it was adopted on 18 February 2020 and will apply from 1 January 2025.

The article explains the context of the review - the problems that it tackles, the objectives of the SME simplification package, the solutions proposed by the Commission and their final shape resulting from the Council discussions.

Keywords: VAT, SME, special scheme, SME exemption

* $\mathrm{PhD}$ in legal studies; the author works at the European Commission, Directorate-General for Taxation and Customs Union. The views expressed in this article are the author's alone and should not be attributed to the European Commission, e-mail: anna nykiel@hotmail.com 


\section{INTRODUCTION - THE COMMISSION'S PROPOSAL}

On 18 January 2018 the Commission adopted a proposal for a Council Directive amending Directive 2006/112/EC on the common system of value added tax as regards the special scheme for small enterprises (hereinafter: "SME package proposal"). ${ }^{1}$ The proposal belongs to the reform package announced in the VAT Action Plan ${ }^{2}$ aimed at modernising the EU VAT system in order to make it simpler, more fraud-proof and businessfriendly. It is closely linked to other legislative initiatives set out in the VAT Action Plan and in particular - the proposal for removing VAT obstacles to cross-border e-Commerce - adopted by the Commission in December $2016^{3}$ and by the Council on 5 December $2017^{4}$ (hereinafter: "e-Commerce Directive") - and the proposals on a definitive VAT system for intra-EU cross-border trade (hereinafter 'definitive VAT system proposals'). ${ }^{5}$

The SME package proposal was subject to a two-year discussion in the Council. Eventually, it was adopted on 18 February 2020 and will apply from 1 January 2025.

${ }^{1} \operatorname{COM}(2018) 21$ final.

${ }^{2}$ Communication from the Commission to the European Parliament, the Council and the European Economic and Social Committee on an action plan on VAT - Towards a single EU VAT area - Time to decide (hereinafter: VAT Action Plan), (COM(2016)148 final).

3 Proposal for a Council Directive amending Directive 2006/112/EC and Directive 2009/132/EC as regards certain value added tax obligations for supplies of services and distance sales of goods (COM(2016)757 final).

${ }^{4}$ Council Directive (EU) 2017/2455 of 5 December 2017 amending Directive 2006/112/EC and Directive 2009/132/EC as regards certain value added tax obligations for supplies of services and distance sales of goods, OJ L 348, 29.12.2017, p. 7. See also the press release VAT on electronic commerce: New rules adopted, https:/eurlex.europa.eu/legal-content/EN/TXT/?uri=uriserv:OJ.L_.2017.348.01.0007.01. ENG\&toc=OJ:L:2017:348:TOC (accessed: 25.06.2018).

${ }_{5}$ Proposal for a Council Directive amending Directive 2006/112/EC as regards harmonising and simplifying certain rules in the value added tax system and introducing the definitive system for the taxation of trade between Member States (COM(2017) 569 final); Proposal for a Council Implementing Regulation amending Implementing Regulation (EU) No 282/2011 as regards certain exemptions for intra-Community transactions (COM(2017) 568 final); Proposal for a Council Regulation amending Regulation (EU) No 904/2010 as regards the certified taxable person $(\operatorname{COM}(2017)$ 567 final). See: https://ec.europa.eu/taxation_customs/business/vat/action-plan-vat/ single-vat-area_en as (accessed: 5.09.2020). 
The proposal aims at updating the VAT rules on the special scheme for SMEs and bringing them closer to the reality of the single market as well as adjusting them to the destination-based taxation.

The purpose of the present article is to present the context of the review - the problems that it tackles, the objectives of the SME simplification package, the solutions proposed by the Commission and their final shape resulting from the Council discussions.

\section{Problems With the current VAT rules for SMEs}

The main problems that the SME package proposal aims to address are linked to the SMEs' compliance costs, lack of neutrality of the current system and VAT revenue losses for Member States. ${ }^{6}$

\subsection{VAT compliance costs}

Small enterprises bear proportionally higher VAT compliance costs than large businesses. ${ }^{7}$ While SMEs spend on average 2.6\% of their sales revenues on tax compliance costs, for large enterprises these costs represent only $0.02 \%$ of their sales revenues. ${ }^{8}$ These costs are linked to complexity of rules on VAT obligations and to diversity of these rules across the EU's Member States.

The complexity of the rules on VAT obligations is such that the majority of small businesses resort to costly advisory services. In reply to the questionnaire published within the framework of an SME panel consultation in 2016 , over $55 \%$ of respondents admitted that they have used services of an external consultant in the last financial year in order to get help to comply with the VAT obligations. ${ }^{9}$

Despite some harmonisation of VAT obligations achieved through the VAT Directive, SMEs wanting to trade cross-border encounter numerous

${ }^{6}$ See Commission Staff Working Document Impact Assessment accompanying the document Proposal for a Council Directive amending Directive 2006/112/EC on the common system of value added tax as regards the special scheme for small enterprises (hereinafter: "Impact Assessment"), Brussels, 18.01.2018, SWD(2018) 9 final, pp. 21-27, 31.

7 See the VAT Action Plan, p. 6; Deloitte, Special scheme for small enterprises under the VAT Directive 2006/112/EC - Options for review, May 2017, vol. 1, pp. 22-27; OECD, Taxation of SMEs in OECD and G20 Countries, 2015, p. 104.

8 See European Commission, European Tax Survey 2004, p. 52.

9 See Impact Assessment, p. 22. 
differences in VAT-related procedures. The 2011 Retrospective Evaluation of VAT showed that on average a firm trading in two EU15 Member States would have to deal with 11 such differences. ${ }^{10}$ The average cost for SMEs to comply with VAT obligations in another Member State is estimated at EUR 4100 annually per Member State they supply to. ${ }^{11}$

As pointed out in the 2011 Retrospective Evaluation, "such intra-EU differences form a source of trade costs that hamper the development of the internal market and discourage cross-border trade." 12

\subsection{Lack of neutrality of the current system}

The current special scheme for small enterprises (hereinafter: "SME scheme") is set in the VAT Directive in a way that results in a negative impact on the competitive situation of suppliers trading both cross-border and domestically.

As regards the cross-border dimension, the problem is linked to the strict territorial limitation of the VAT exemption, which means that only small enterprises established within the Member State of taxation may benefit from it (Article 283(c) of the VAT Directive). In a system evolving towards taxation at destination this constitutes a serious problem as it means that there is no level playing field for small enterprises trading within the Single Market.

The introduction of the common EU threshold by the e-Commerce directive improves the situation, but to a limited extent only. The common EU threshold only covers B2C supplies and allows enterprises to treat these cross-border supplies as domestic if their annual turnover generated from such supplies does not exceed EUR $10000 .^{13}$

${ }^{10}$ Institute for Fiscal Studies (IFS) and others, A retrospective evaluation of elements of the EU VAT system (hereinafter: 2011 Retrospective Evaluation), 2011, p. 15; https:// eur-lex.europa.eu/legal-content/EN/TXT/PDF/?uri=SWD:2018:9:FIN\&rid=1 (accessed: 28.06.2018). The study refers in this context to two EU15 Member States. Countries that joined the EU in the 2004 enlargement have fewer administrative differences in their VAT regimes than the EU15 countries. A possible reason is that these countries were able to design VAT systems while adapting best-practice procedures from the EU15 countries.

${ }_{11}$ Deloitte Study for the Commission on Modernising VAT for cross-border e-Commerce - Lot 1, p. 45. This study refers to the notion of an SME in the sense of the general definition as set out in Recommendation 2003/361.

122011 Retrospective Evaluation, p. 15.

13 See Article 58(2)(c) of the VAT Directive as introduced by the e-Commerce Directive. For more explanation see also Impact Assessment, p. 37. 
Due to the competitive disadvantage on the side of non-established enterprises as compared to domestic suppliers, SMEs are discouraged from engaging in cross-border operations and do not exploit the opportunities that the Single Market is aimed to bring. This was confirmed already during the public consultation that followed the 2010 Green Paper on the future of VAT ${ }^{14}$ and then in the 2017 Deloitte SME study ${ }^{15}$ as well as in a public consultation carried out by the Commission in spring $2017 .{ }^{16}$

Apart from the cross-border issues, lack of neutrality of the current SME exemption system has a distortive effect on domestic markets, which is linked to the so-called threshold effect. The latter relates to the fact that suppliers of a very similar size as exempt SMEs are not able to benefit from the exemption because they have exceeded the threshold. This distortive effect is inherent in any threshold. In addition, the existence of the threshold may prevent SMEs from growing as they limit their turnover in order not to fall out of the scope of the exemption. This conclusion is supported by a finding of high concentration of enterprises immediately below the threshold. ${ }^{17}$

Finally, another feature of the non-neutral EU VAT system that strengthens its distortive effects is linked to the divergence of national rules on VAT obligations. The costs that companies need to bear in order to adapt to VAT regimes in other Member States constitute a trade barrier inhibiting the completion of the Single Market. ${ }^{18}$

2.3. VAT revenue losses

VAT revenue losses for Member States stem from both the VAT foregone due to the SME exemption and from non-compliance linked to the complexity of the VAT rules and to the divergence of the rules in place in different Member States.

Member States choose to forgo the VAT that could be collected from SMEs because they want to support these enterprises and create growth friendly conditions for them. The 2017 Deloitte SME study estimates the gross VAT revenue that exempt small businesses would generate at EUR

${ }^{14}$ Green Paper on the future of VAT - Towards a simpler, more robust and efficient VAT system (COM(2010) 695 final).

152017 Deloitte SME study, vol. 1, p. 45.

16 See Impact Assessment, pp. 24-25.

172017 Deloitte SME study, vol. 1, pp. 121-122.

18 See Impact Assessment, p. 25. 
13.4 billion, which amounts to $1.3 \%$ of net VAT revenues. However, given that businesses would be able to deduct their input VAT, the actual net VAT revenue at stake would rather be at the level of EUR 3.8 billion or $0.4 \%$ of net VAT revenues collected in the EU. ${ }^{19}$

The non-compliance of SMEs with VAT rules is not always due to fraudulent intentions on the side of businesses, but also to complexity and diversity of the rules on the VAT obligations across the Member States. The 2011 IFS retrospective evaluation of the VAT system study estimated that a $10 \%$ reduction in differences in VAT procedures could boost intra-EU trade by up to $3.7 \%$ and the GDP by up to $0.4 \% .^{20}$

Monitoring of the compliance with the SME scheme rules is not an easy task for national tax administrations. As the SMEs applying the exemption in general do not file VAT returns, the verification as to whether their turnover does not exceed the exemption threshold may be challenging. ${ }^{21}$

\section{Solutions SET OUT IN THE COMMISSION'S PROPOSAL}

In view of the above problems with the current rules on the SME special scheme, the main objectives of the Commission's proposal were to:

- reduce VAT compliance costs for SMEs both domestically and at EU level,

- reduce distortions of competition at both these levels,

- reduce the negative impact of the threshold effect and

- facilitate compliance by SMEs and monitoring by tax administrations. ${ }^{22}$ The proposal is set to achieve these objectives through:

- opening of the exemption to non-established SMEs,

- establishing an updated value for the maximum level of national exemption thresholds,

- introducing a transitional period during which SMEs that temporarily exceed the domestic exemption threshold would be able to continue benefitting from the exemption,

- $\quad$ introducing simplified VAT obligations for both exempt and non-exempt SMEs.

19 See Impact Assessment, p. 26 and 2017 Deloitte study, vol. 1, p. 123.

202011 IFS retrospective evaluation of the VAT system study, p. 15.

21 See Impact Assessment, p. 27.

${ }^{22}$ See Proposal for a Council Directive amending Directive 2006/112/EC on the common system of value added tax as regards the special scheme for small enterprises Brussels, 18.01.2018, COM(2018)21 final, Explanatory memorandum, p. 2. 
3.1. Opening of the SME exemption to non-established businesses

Point 11 of Article 1 of the proposal deletes letter c) of Article 283(1) of the VAT Directive stating that the arrangements regarding the SME exemption do not apply to supplies of goods or services carried out by a taxable person who is not established in the Member State in which the VAT is due. This amendment effectively opens the exemption to the EU enterprises not established in the Member State where they carry out supplies subject to VAT and allows equal treatment in terms of VAT taxation of both domestic suppliers and the suppliers from other Member States.

3.2. Exemption threshold and eligibility condition

The proposal amends Article 284 of the VAT Directive allowing Member States that decide to implement the SME exemption, to set their national exemption threshold at the level that best reflects their economic reality. In order to ensure that the exemption benefits the smallest enterprises, the proposal sets the maximum level of the exemption threshold at EUR 85000 - the same for all the Member States. This common maximum exemption threshold replaces the multitude of maximum thresholds currently set for the individual Member States both in the provisions of the VAT Directive itself as well as through a number of derogations. As a result, according to the data available on 1 July 2019, the SME exemption thresholds ranged from about EUR 2845 in Sweden to an equivalent of EUR 94741 in the UK. ${ }^{23}$

Under the new system, if a small enterprise wants to benefit from the exemption in a Member State in which it is not establish, it must meet two conditions:

- Its annual turnover in the Member State concerned (the Member State annual turnover) must remain below the exemption threshold applicable in that Member State and

- Its overall turnover in the EU (Union annual turnover) must not be higher than EUR 100000.

${ }^{23}$ See the VAT thresholds table available on DG TAXUD's website at https://ec.europa.eu/taxation_customs/sites/taxation/files/resources/documents/taxation/vat/traders/ vat_community/vat_in_ec_annexi.pdf (accessed: 5.10.2020). 
The above second eligibility condition is aimed at preventing abuse by large enterprises that otherwise could be using the exemption in several Member States despite having a large total turnover, if their turnover in each Member State were below the national exemption threshold.

\subsection{Transitional period}

The proposal introduces new Article 288a to the VAT Directive, which provides for a transitional period for small enterprises making use of the SME exemption, whose Member State annual turnover exceeds the exemption threshold in a given year. These small enterprises will be able to benefit from the SME exemption for that one year, provided that their turnover does not exceed the threshold by more than $50 \%$. Article 288 a establishes therefore two safeguards against the abuse of the measure: the time limit (1 year) and the turnover limit (exceeding the domestic Member State annual turnover threshold by more than 50\%). It should be noted that the transitional period does not apply in a situation in which the Union annual turnover of an enterprise exceeds EUR 100 000. In such a case, a small enterprise cannot benefit anymore from the SME exemption in any Member State in which it is not established.

3.4. Simplified VAT obligations for both exempt and non-exempt SMEs

The proposal introduces a new Section 2a to Title XII, Chapter 1 on simplified obligations for both exempt and non-exempt small enterprises. The new subsection 1 provides for a number of simplified obligations for exempt enterprises. These concern registration, invoicing, keeping of accounts and VAT returns. In addition, Member States retain the competence to release exempt SMEs from other obligations referred to in Articles 213 to 271 of the VAT Directive.

Due to the fact that exempt SMEs cannot deduct the input VAT, not all eligible enterprises may be interested in using the SME exemption. In particular, enterprises supplying to other taxable persons may want to opt for taxation on the basis of the general rules. These SMEs may reduce their VAT compliance costs mainly thanks to simplified VAT obligations and not to the exemption itself. Subsection 2 on simplified obligations for non-exempt small enterprises offers therefore a solution to this group of small enterprises. In addition, it applies also to those small enterprises that achieve 
turnover above the exemption threshold, but below EUR 2000 000, who therefore qualify as small enterprises within the meaning of Article 280a (1) introduced by the proposal.

The set of simplified obligations for non-exempt small enterprises introduced by the Commission's proposal covers simplified registration, record keeping and longer tax periods.

\subsection{Monitoring and exchange of information}

In order to allow Member States to effectively monitor and control the application of the SME scheme provisions, collection of the relevant information and its exchange between national tax administrations must be ensured. Article 284(4) second paragraph introduced by the proposal stipulates that where a small enterprise avails itself of the exemption in Member States in which it is not established, the Member State of establishment must take all measures necessary to ensure the accurate declaration of the Union annual turnover and the Member State annual turnover by the small enterprise. The Member State of establishment must then provide this information to the tax authorities of the other Member States concerned in which the small enterprise carries out its supplies.

\section{Council Directive (EU) 2020/285}

As mentioned at the beginning of this article, the Commission's proposal was subject to discussions in the Council during two years and was eventually adopted on 18 February 2020.

Directive 2020/285 retains the main concept of a special scheme for small enterprises optional for both Member States and taxpayers to apply. In addition to granting an exemption from VAT, the special schemes currently also allow for graduated tax relief. Graduated tax relief is considered to constitute a source of complexity and to contribute little to reducing the compliance burden of small enterprises. Directive 2020/285 removes therefore this measure. ${ }^{24}$

The main characteristics of the SME scheme eventually retained in Directive 2020/285 are discussed below.

${ }^{24}$ See recital 17 and amendments to Articles 282, 284, deletion of Article 285. 
4.1. Opening of the exemption to non-established SMEs, exemption threshold and the eligibility condition

Directive 2020/285 retained the crucial element of the proposal regarding the opening of the SME exemption to non-established small enterprises. It kept the maximum domestic exemption threshold at the level of EUR 85000 of Member State annual turnover and the eligibility condition for access to exemption in the Member States other than the one of the establishment at the maximum level of EUR 100000 of the annual Union turnover.

\subsection{Single window}

An important element of the reform is that it offers SMEs a single window for registration and reporting in their own Member State.

In order for an SME to avail itself of the exemption in a Member State in which it is not established, that SME must give prior notification to the Member State of established and be identified for the application of the exemption by an individual number in the Member State of establishment only. ${ }^{25}$ If such an SME subsequently wants to use the exemption in Member States other than the ones indicated in prior notification or wants to cease applying the exemption in Member States in which it is not established, it needs to inform the Member State of establishment in advance through an update to a prior notification. ${ }^{26}$

As mentioned above, also the periodic (quarterly) reporting on the total value of supplies both in the Member State of establishment and in other Member States must be done in the Member State of establishment. The latter must be informed as well when the Union annual turnover threshold is exceeded ${ }^{27}$.

\subsection{Transitional period}

The Directive further developed the concept of the transitional period. Newly introduced Article 288a(1) stipulates that where during a calendar year the Member State annual turnover threshold is exceeded by not more

25 Article 284(3) introduced by Directive 2020/285.

${ }^{26}$ Article 284(4) introduced by Directive 2020/285.

27 Article 284b(1) and (3) introduced by Directive 2020/285. 
than $10 \%$, a taxable person must be able to continue to benefit from the SME exemption during that calendar year. Where this threshold is exceeded by more than $10 \%$, the SME exemption ceases to apply as of that time.

Member States may, however, set the ceiling higher - at $25 \%$ or even allow the taxable person to continue to benefit from the exemption without any ceiling during the calendar year when the threshold is exceeded. However, the application of this ceiling or option may not result in the exemption being granted to a taxable person whose turnover within the Member State granting the exemption exceeds EUR 100000.

Contrary to the Commission's proposal, in which the transitional period was obligatory for Member States to apply, the Directive makes the application of transitional period optional for Member States.

The transitional period does not apply in the situations, in which the Union annual turnover threshold is exceeded.

It is worth noting that, in addition, in order to prevent circumvention of the rules regarding the SME exemption and to preserve its purpose, Article $288 \mathrm{a}(1)$ stipulates that a taxable person, whether or not established in the Member State granting the exemption, cannot benefit from the exemption where the national threshold laid down therein was exceeded in the preceding calendar year. For the same reasons, a taxable person not established in the Member State granting the exemption will not be able to benefit from the exemption where the Union annual turnover threshold was exceeded in the preceding calendar year. ${ }^{28}$

\subsection{Simplified VAT obligations for exempt SMEs}

Directive 2020/285 retains the section concerning simplification of obligations for exempt small enterprises. It includes simplified registration, reporting and the possibility, broadly existing already today, ${ }^{29}$ for Member States to release exempt small enterprises from certain or all obligations referred to in Articles 217 to 271.

The Directive does not, however, include the section on simplified obligations for non-exempt small enterprises, which could be found in the Commission's proposal. As mentioned above, the purpose of that section was to address the needs of SMEs which for different reasons are not

\footnotetext{
${ }^{28}$ See Article 288a(2) introduced by Directive 2020/285. See also recital 13.

29 Article 272(1)(d) of the VAT Directive.
} 
exempt. In this way, the proposal attempted to introduce a new, extended concept of small enterprise, which would encompass both exempt and non-exempt SMEs whose Union annual turnover would not be higher than EUR 2000 000..$^{30}$ This idea was abandoned in Directive 2020/285.

\subsection{Exchange of information between Member States}

During the Council discussions on the proposal, the provisions aimed at ensuring effective control and monitoring of the application of the SME scheme and the exchange of information between national tax administrations have been substantially developed. In this regard it turned out necessary to amend Regulation $904 / 2010$ on administrative cooperation ${ }^{31}$ so that Member States could have automated access to the data collected from the SMEs benefiting from the VAT exemption. ${ }^{32}$

The amendments to Regulation 904/2010 stipulate therefore that the information collected from the exempt SMEs must be stored by Member States in their electronic systems and that the competent authorities of any other Member State must have automated access to it. ${ }^{33}$ Moreover, they include provisions regarding the transmission of information by electronic means between the Member State of establishment and the Member State granting the exemption - in both directions. Furthermore, they oblige the Commission to adopt by means of implementing acts the technical details for the transmission of the relevant information. ${ }^{34}$

Finally, the newly introduced provisions of the Regulation foresee that the Commission should, on the basis of the information provided by the Member States, publish on its website the modalities of application of the SME scheme in different Member States. ${ }^{35}$

30 See Article 280a(1) introduced in the Commission's proposal.

31 Council Regulation (EU) No 904/2010 of 7 October 2010 on administrative cooperation and combating fraud om the field of value added tax, OJ L 268, 12.10.2010, p. 1.

32 See recital 22.

33 See amendments to Articles 17 and 21 of the Regulation.

${ }^{34}$ See Articles 37a and 37b of the Regulation introduced by Directive 2020/285.

35 See amendment to Article 32 of the Regulation introduced by Directive 2020/285. 
The Directive that was supposed to deliver the simplification package for SMEs ended up with a text which is not very simple. However, in order to reach a compromise on the package in the Council, it was necessary to clarify the details on administrative cooperation, exchange of information and control of the functioning of the SME scheme. The compromise text is complex because it covers all these issues. What is important is that the objectives of the original proposal are largely preserved. The Directive will result in the reduction of VAT compliance costs for SMEs and more level playing field for them.

The Directive provides simplification for both SMEs and tax administrations that would not be achievable without it. It opens exemption to nonestablished SMEs and offers them a single window for registration and reporting in their own Member State. Moreover, it provides some simplified obligations for exempt SMEs. Furthermore, it sets one maximum exemption threshold and an anti-abuse safeguard for all the Member States. Finally, it enables tax administrations to collect and exchange information on SMEs in a uniform manner and to better control the application of the scheme.

For the new SME scheme to function the Commission will have to adopt the implementing acts setting a number of technical details. As mentioned at the beginning of this article, the provisions on the new special scheme for small enterprises will apply as of 1 January 2025.

\section{REFORMA PRZEPISÓW DOTYCZĄCYCH PROCEDURY SZCZEGÓLNEJ DLA MAEYCH PRZEDSIĘBIORSTW NA MOCY DYREKTYWY VAT 2006/112/WE}

Streszczenie. W dniu 18 stycznia 2018 r. Komisja przyjęła wniosek dotyczący dyrektywy Rady zmieniającej dyrektywę 2006/112/WE w sprawie wspólnego systemu podatku od wartości dodanej w odniesieniu do procedury szczególnej dla małych przedsiębiorstw. Wniosek należy do pakietu reform zapowiedzianego w planie działania w sprawie VAT, którego celem jest modernizacja unijnego systemu VAT, tak aby był on prostszy, bardziej odporny na oszustwa i przyjazny dla przedsiębiorstw. Wniosek ma na celu aktualizację przepisów dyrektywy VAT dotyczących procedury szczególnej dla MŚP oraz dostosowanie ich do realiów jednolitego rynku oraz do systemu opodatkowania opartego na miejscu przeznaczenia.

Wniosek w sprawie pakietu dotyczącego MŚP był przedmiotem dwuletniej dyskusji w Radzie. Ostatecznie został przyjęty w dniu 18 lutego 2020 r. i będzie miał zastosowanie od dnia 1 stycznia 2025 r.

W artykule wyjaśniono kontekst reformy - problemy, których dotyczy, cele pakietu uproszczeń dla MŚP, rozwiązania zaproponowane przez Komisję i ich ostateczny kształt będący wynikiem dyskusji na forum Rady.

Słowa kluczowe: VAT, małe i średnie przedsiębiorstwa, procedury szczególne, zwolnienie dla małych i średnich przedsiębiorstw 